\title{
Nasopharyngeal hirudiniasis: a hidden culprit-a case report
}

\author{
Shreya Agarwal and Nimish Gupta* (D)
}

\begin{abstract}
Background: Leech infestation in the nose or nasopharyngeal region is a rare occurrence. The most common known cause is drinking water from natural water sources like ponds and rivers. Its hidden location of attachment in the nasopharynx and its uncommon occurrence make it easy to miss during diagnosis.

Case presentation: We present a case of a 61-year-old male patient with recurrent unilateral epistaxis without any apparent cause. He was diagnosed with leech infestation in the nasopharynx on endoscopic examination. This article reports the management of nasopharyngeal leech infestation and safety measures for this animate foreign body retrieval.

Conclusion: A vigilant approach, thorough history, and examination are a must. Though leeches are simple to remove most of the time, certain necessary precaution should be kept in mind for better management and prevention of further complications.
\end{abstract}

Keywords: Case report, Nasopharyngeal hirudiniasis, Leech infestation, Epistaxis, Nasal stuffiness

\section{Background}

Epistaxis and nasal stuffiness are common issues reported in otorhinolaryngology or maxillofacial surgery OPDs. There can be an array of causes associated with this symptom. The probability can span from simple reasons like exposure to warm dry air for a long time or injury from nose picking, to the presence of foreign body or tumors of the nose and paranasal regions. Another common complaint is lodgment of a foreign body. Inanimate objects are more frequently seen lodged in the nasal cavity than animate foreign bodies, especially in a well-oriented person. Among the animate ones, maggots are more common. But they too are generally seen in challenged, debilitated individuals. An animate foreign object causing such regular symptoms in an oriented patient is rare and many times missed on cursory examination. Here we present a case of nasopharyngeal hirudiniasis, i.e., leech infestation in the nasopharynx. Though leech infestation is not frequently seen and could be a rare cause for unilateral epistaxis and nasal

\footnotetext{
* Correspondence: dr.gupta.1088@gmail.com
}

Swami Vivekananda Hospital, Dharmawala, India stuffiness, a thorough and careful history can be helpful in raising suspicion for the same. There is no specific clinical procedure for its management and treatment mainly depends on the ingeniousness of the clinician and available resources. The two basic guidelines to be followed are to remove the parasite at the earliest opportunity and to retrieve it in toto, as breaking it might lead to further complications.

\section{Case presentation}

A 61-year-old man was reported to the outpatient department with a history of frequent nasal obstruction and bleeding from the nose. The patient also reported an occasional weird wriggling sensation at the back of his nose and throat, which led him to suspect some insect. The patient said the sensation started 27 days back when he was drinking water from a pond near his village. Though the nasal bleed from the right nostril was frequent in the initial few days, it stopped later on by itself. As the patient resides in the interior village of hills, medical advice was not easily approachable and because the bleeding stopped after few days, the patient did not 
seek any medical opinion. Presently, his only concern was the feeling of a stuffy nose and an occasional sensation of movements at the back of his nose and throat.

On anterior rhinoscopy, nasal cavities bilaterally were found clear otherwise, except for blood crust in the right nostril region. There was no other significant medical history of the patient. For further confirmation, nasal endoscopy was planned. A brownish-black moving foreign body was detected in the nasopharyngeal region, on endoscopy using 0-degree rigid endoscope (Fig. 1). An animate foreign body was suspected because of its appearance and movements. Few attempts were made to retrieve the entity through the nose, but its continuous motion, slippery nature, and firm adherence to mucosa made it difficult to do so. The nasal cavity was then sprayed with $4 \%$ xylocaine nasal spray and was packed with ribbon gauze immersed in xylocaine jelly for 10 min. Intention was to anesthetize nasal mucosa as well as the parasite. After removal of the nasal pack, the foreign body was detached from its nasal attachment with forceps. In the process of detaching, it got somewhat pushed further. Finally, the unattached worm was extracted through the mouth by grasping its posterior end with Luc's forceps (Fig. 2)
A blackish-brown, elongated cylindrical worm measuring approximately $8 \times 1.5 \mathrm{~cm}$, with a large anterior sucker, and a smaller distal sucker was confirmed as a leech, who was still alive and was making active movements (Fig. 3). There was an active mild posterior nasal bleed for few minutes, post removal of leech which stopped on pressure. Confirmatory endoscopy was again performed to look for the presence of other leeches or any leftover segment of the worm, although the presence of suckers on both ends confirmed its complete retrieval. The patient was discharged after a period of observation and was completely asymptomatic in his follow-up visits in the next two months. The patient was well satisfied with the treatment intervention.

\section{Discussion}

Leeches are parasitic worms that mainly survive on the blood of their vertebrate host. One way of classifying them is based on their location, terrestrial or aquatic. Land leeches have powerful jaws that can penetrate the skin in order to attach themselves anywhere on the external surface of the body. In contrast, aquatic leeches have weak jaws and require soft tissue, such as the mucous membrane of the upper aerodigestive tract, to feed on [1].

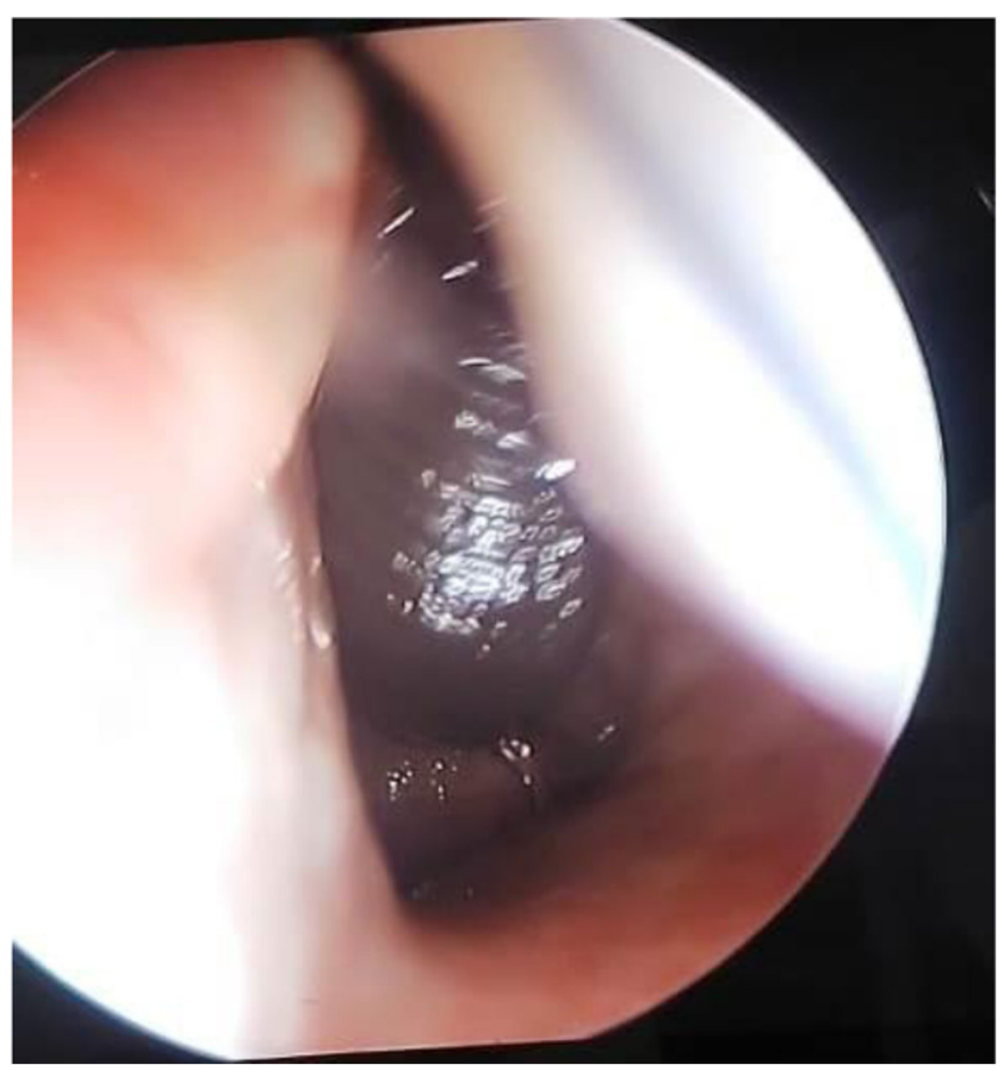

Fig. 1 Endoscopic view of nasopharynx depicting animate foreign body infestation 


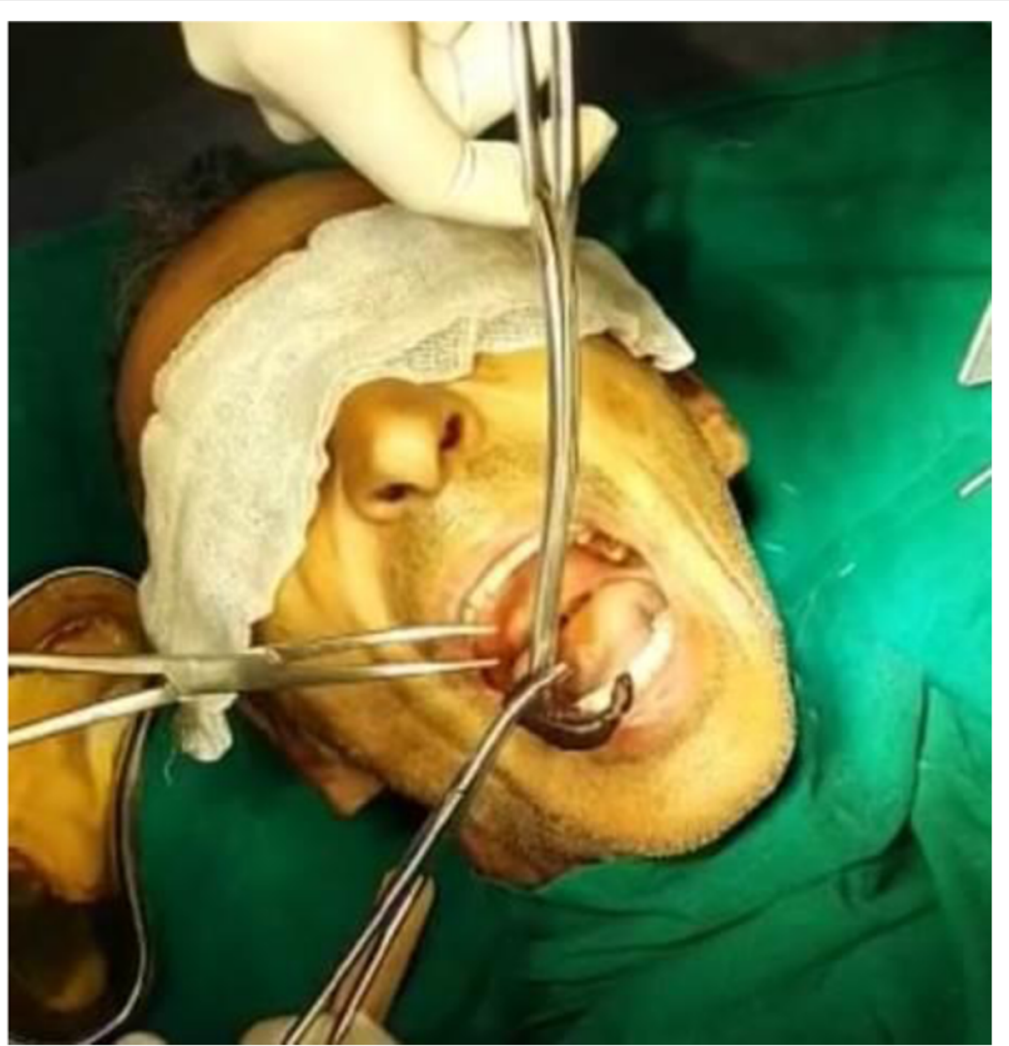

Fig. 2 Retrieval of leech via the oral cavity

Once they attach to the host, their saliva is the sole and most potent tool to invade host defense. It has a local anesthetic agent, which masks the host invasion by anesthetizing the region of attachment, a vasodilator, similar to histamine which aids in local blood flow, an anticoagulant Hirudin, to prevent blood coagulation and cause mucosal bleeding, and hyaluronidase which facilitates the distribution of other salivary enzymes into the host. Hirudin is considered as the most potent naturally occurring anticoagulant and its effect may last for several hours, even after the leech detaches from the host. A leech can cause severe anemia in the host as it can ingest blood up to 8 to 9 times of its body weight [2].

Though a variant species of leeches, Hirudo medicinalis, have been used in the field of medicine and surgery to suck blood from the patients [3] for the treatment of various conditions like hypertension or for keeping the flaps viable, parasitic infestation by leech causing epistaxis is a potentially dangerous condition needing immediate attention. As various literatures report, leech infestation is common with unsafe water drinking habits. The upper aerodigestive tract is the site frequently affected. The nose is the most common site of infestation (71\%), with epistaxis being the most prominent symptom. Other sites include hypopharynx (14\%), nasopharynx, and oropharynx (7\%) [4].
In the nose or nasopharynx, leech infestation can exhibit symptoms common to many other otolaryngology diseases. The patients can complain of bleeding nose, obstruction of the nose, or the sensation of a foreign body moving around in the nose [5]. Other common symptoms are recurrent blood in the mouth, odynophagia, difficulty in swallowing and breathing, and at times, hemoptysis, depending upon the various sites of infestation [6], though nasopharyngeal leech infestation should be taken as an emergency because it can cause severe blood loss as well as it can slip forward into the larynx, which could lead to life-threatening airway obstruction $[7,8]$. Many times, the endoparasitism persists for a long time before actual intervention by a clinician, because of the inconspicuous site of infestation and the absence of pain [9].

Previously reported cases of nasopharyngeal leech infestation, its causes, and management adopted are mention in Table 1.

There are certain cautions to be remembered while treating these parasites.

Firstly, they should be removed as soon as possible because a prolonged infestation may lead to severe blood loss $[10,11]$. Many a time these leeches detach from the host by themselves, once it has fed to its limit. This may sometimes escalate the complications if it progresses 


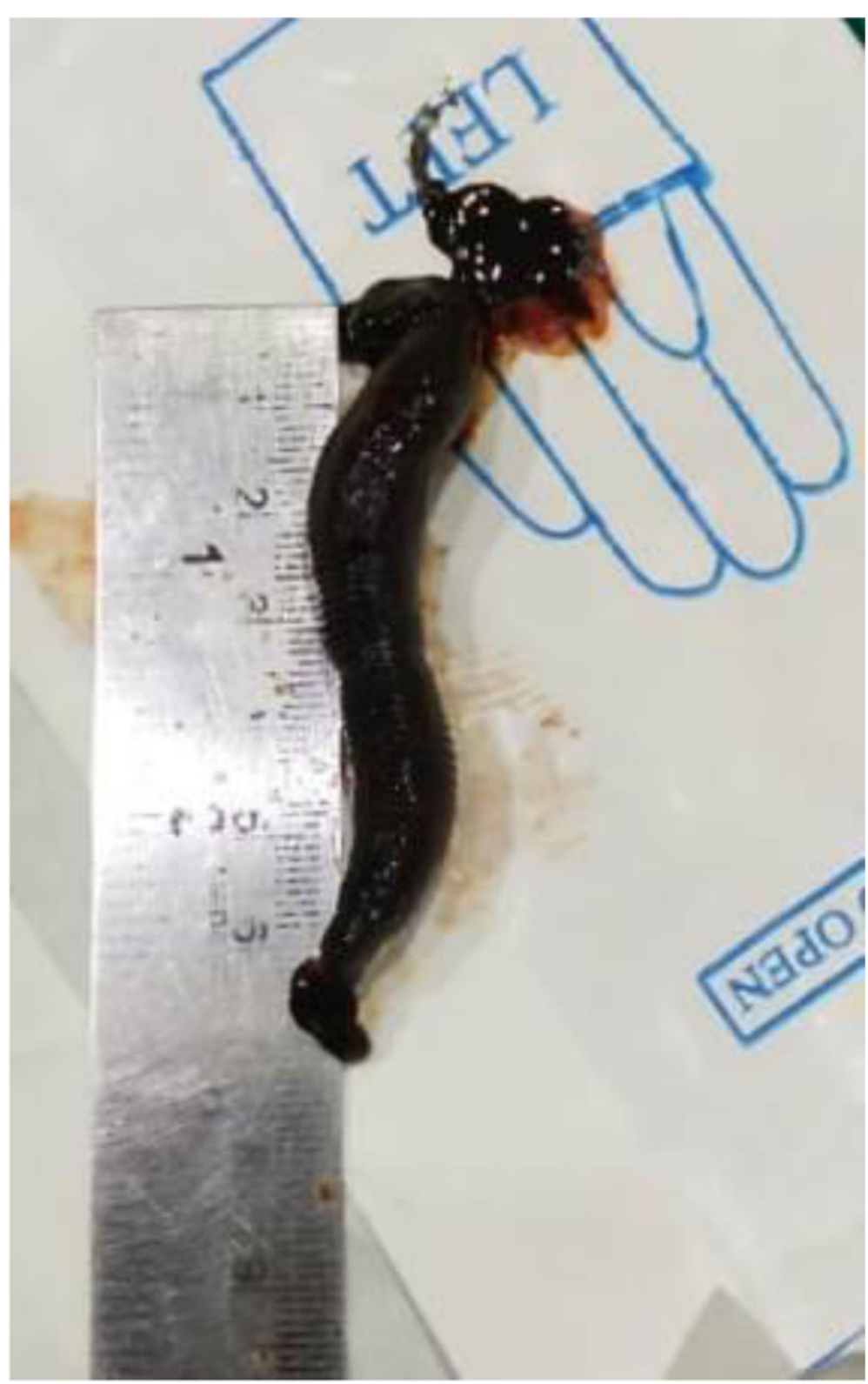

Fig. 3 Intact leech removed from the nasopharynx

further into the gastrointestinal or respiratory tract. Luckily, in our patient, the leech remained attached in the nasopharynx for almost four weeks.

Secondly, a gentle removal without any forceful pulling is advisable as they have a firm grip, and pulling with undue pressure can cause the small segment near the mouth to break, which might lead to chronic foreign body infection. Forceful pulling can also lead to spillage of contaminated gastric contents of leech into the host wound. Leeches are known to loosen their grip on the application of few chemicals like alcohol, vinegar, turpentine oil, salt, xylocaine, and $10 \%$ tartaric acid [12].
Application of any of these might help to remove the firmly adherent parasite.

Thirdly, thorough examination to rule out the possibility of more than one leech infestation is essential as $4-5$ eggs are laid in cocoons, so many a times their larva reside in groups. Few clinicians have reported multiple leeches in single nasal cavity $[13,14]$ or in both nasal cavities [15].

\section{Conclusion}

The rare occurrence of nasal hirudiniasis, presence of very common symptoms, discreet locations of 
Table 1 Previously reported cases of nasopharyngeal leech infestation

\begin{tabular}{|c|c|c|c|c|c|c|}
\hline Author & Year & Place & No. of cases & Symptoms & Management & Cause \\
\hline Golz et al. [16] & 1989 & Israel & 17 & $\begin{array}{l}\text { Epistaxis, blood spitting, and } \\
\text { severe hemorrhage in } 3 \\
\text { cases }\end{array}$ & $\begin{array}{l}\text { Removed by quick pull by } \\
\text { forceps }\end{array}$ & $\begin{array}{l}\text { Drinking water from } \\
\text { streams or freshwater } \\
\text { lakes }\end{array}$ \\
\hline $\begin{array}{l}\text { Bilgen et al. } \\
\text { [17] }\end{array}$ & 2002 & Turkey & 1 & $\begin{array}{l}\text { Nasal obstruction and } \\
\text { intermittent epistaxis }\end{array}$ & $\begin{array}{l}\text { Detached by instrument and } \\
\text { spitted out }\end{array}$ & $\begin{array}{l}\text { Contaminated pool } \\
\text { swimming }\end{array}$ \\
\hline Raza et al. [13] & 2006 & Pakistan & $\begin{array}{l}7 \% \text { cases out of } 14 \text { were } \\
\text { reported in the } \\
\text { nasopharynx }\end{array}$ & $\begin{array}{l}\text { Hematemesis, epistaxis, } \\
\text { pallor }\end{array}$ & $\begin{array}{l}\text { Removed by ENT surgeon under } \\
\text { Local anesthesia }\end{array}$ & $\begin{array}{l}\text { Contaminated water } \\
\text { consumption }\end{array}$ \\
\hline Razi [18] & 2007 & Iran & 1 & Blood in cough and saliva & Forceps removal & $\begin{array}{l}\text { Spring water } \\
\text { consumption }\end{array}$ \\
\hline $\begin{array}{l}\text { Ismail lynen } \\
\text { et al. [19] }\end{array}$ & 2010 & Turkey & 3 & Epistaxis, hemoptysis & Forceps removal & $\begin{array}{l}\text { Well water } \\
\text { consumption }\end{array}$ \\
\hline $\begin{array}{l}\text { Mehmet Fatih } \\
\text { Garça et al. } \\
\text { [20] }\end{array}$ & 2011 & Turkey & 1 & Oral bleed, epistaxis & $\begin{array}{l}\text { Endoscopic removal after } 4 \% \\
\text { pantocaine and oxmetazolin } \\
\text { application }\end{array}$ & $\begin{array}{l}\text { Spring water } \\
\text { consumption }\end{array}$ \\
\hline $\begin{array}{l}\text { Saeid } \\
\text { Sadeghian } \\
\text { et al. [21] }\end{array}$ & 2020 & Iran & 1 & $\begin{array}{l}\text { Hematemesis, epistaxis, and } \\
\text { fecal blood }\end{array}$ & $\begin{array}{l}\text { Clamp removal without local } \\
\text { anesthesia }\end{array}$ & $\begin{array}{l}\text { Drinking water from } \\
\text { well }\end{array}$ \\
\hline
\end{tabular}

attachment, and absence of pain are few reasons that this entity is commonly missed or overlooked. Clinicians attending patients in tropical, hilly, rural regions should be vigilant about the possibility of leech infestation. It is a common practice in rural hill regions to drink water from ponds, lakes, or other natural water sources, which is the most common source of such parasitic invasion. Though once their location is confirmed, most of the time leech retrieval is simple. Sometimes due to slippery nature, firm attachment, and inaccessibility the removal becomes challenging. Few basic concepts which we tried to enlist in the article should be of help to manage such cases and prevent further complications.

\section{Acknowledgements}

No other acknowledgements are required.

\section{Authors' contributions}

SA was the operating ENT surgeon and NG was involved in the clinical and investigative workup of the patient. NG was a major contributor in writing the manuscript. Both authors have read and approved the final manuscript.

\section{Funding}

Not applicable. There were no funding sources related to this manuscript.

\section{Availability of data and materials}

Not applicable. The manuscript does not contain any data. The rest of all information is included in this manuscript.

\section{Declarations}

\section{Ethics approval and consent to participate}

All procedures performed in studies involving human participants were in accordance with the ethical standards of the institution and with the 1964 Helsinki Declaration and its later amendments or comparable ethical standards. Consent to participate was taken from the patient.

\section{Consent for publication}

The written consent for publication was obtained from the patient in his native language.
Competing interests

The authors declare that they have no competing interests

Received: 6 May 2021 Accepted: 10 June 2021

Published online: 13 July 2021

References

1. Pandey CK, Sharma R, Baronia A, Agarwal A, Singh N (2000) An unusual cause of respiratory distress: live leech in the larynx. Anesth Analg 90(5): 1227-1228. https://doi.org/10.1097/00000539-200005000-00044

2. Uygur K, Yasan H, Yavuz L, Dogru H (2003) Removal of a laryngeal leech: a safe and effective method. Am J Otolaryngol 24(5):338-340. https://doi. org/10.1016/S0196-0709(03)00058-9

3. Payton B (1981) In: Kenneth M, Nicholls J, Stent G (eds) Neurobiology of the leech. Cold Spring Harbor Laboratory, NewYork, pp 7-26 ISBN 0 87969-146-8

4. Dutta S, Saha S, Pal S (2016 Mar) Epistaxis Due to Leech Infestation in Nose: A Report of Six Cases and Review of Literature. Indian J Otolaryngol Head Neck Surg 68(1):42-45. https://doi.org/10.1007/s12070-014-0728-0

5. Chow CK, Ho ACW (2005) Unilateral epistaxis after swimming in a stream. Hong Kong Med J 11(2):55-57

6. Ghimire A, Acharya A (2008) Unusual cause of unilateral epistaxis: nasal leech infestation. JNMA J Nepal Med Assoc 47(169):38-40

7. Mekonnen D (2013) Leech infestation: the unusual cause of upper airway obstruction. Ethiop J Health Sci 23(1):65-68

8. Anajar S, Ansari R, Hassnaoui J, Abada R, Roubal M, Mahtar M (2017) An unusual cause of severe dyspnea: A laryngeal live leech: Case report. Int J Surg Case Rep 32:9-11. https://doi.org/10.1016/j.ijscr.2016.12.007

9. Saki N, Rahim F, Nikaghlagh S, Saki G (2009) Meta-analysis of the leech as a live foreign body: detection, precaution and treatment. Pak J Biol Sci 12(24): 1556-1563. https://doi.org/10.3923/pjbs.2009.1556.1563

10. Saha PK, Roy S, Bhattacharya D, Mukherjee P, Naskar T, Bhuiya A (2005) Leech bite: a rare gynecologic emergency. MedGenMed 7(4):73

11. Cundall DB, Whitehead SM, Hechtel FO (1986) Severe anaemia and death due to the pharyngeal leech Myxobdella africana. Trans R Soc Trop Med Hyg 80(6):940-944. https://doi.org/10.1016/0035-9203(86)90265-8

12. Hunter's Tropical Medicine and Emerging Infectious Disease (Ninth Edition) Animals hazardous to humans, 2013, Chapter 134, Pages 938-965.

13. Raza SN, Shabbir SM, Anwar-ul-Haq S (2006) Leech infestation and its association with water drinking habits. J Coll Physicians Surg Pak 16(3):175178

14. Satyawati SSK, Dass A (2002) Multiple live leeches from nose in a single patient- a rare entity. Indian J Otolaryngol Head Neck Surg 54:154

15. Chen WC, Chien CY, Yang CH, Li JH, Hwang CF (2010) Nasal leech infestation: report of seven leeches and literature review. Eur Arch 
Otorhinolaryngol 267(8):1225-1229. https://doi.org/10.1007/s00405-009-11 88-0

16. Golz A, Zohar S, Avraham S, Joachims HZ, Danino J, Merzbach D (1989) Epistaxis caused by leeches. Harefuah 117:141-143

17. Bilgen C, Karci B, Uluoz U (2002) A nasopharyngeal mass: Leech in the nasopharynx. Int J Pediatr Otorhinolaryngol 64(1):73-76. https://doi.org/10.1 016/S0165-5876(02)00041-1

18. Razi E (2007) Aquatic leech infestation: A rare cause of hemoptysis. Case Rep Clin Pract Rev 8:125-127

19. Iynen I, Sogut O, San I, Bozkus F, Gokdemir M (2010) A Rare Cause of Epistaxis, Hemoptysis and Anemia: Leech in the Nasopharynx. Journal Of Medical Cases 1(2):71-73

20. Garça MF, Yelken MK, Okur MH, Yuca SA (2011) Leech Infestation of the Nasopharynx; A Rare Cause of Epistaxis and Hemorrhage. Eur J Gen Med 8(2):141-143

21. Sadeghian S, Sharafi N, Sadeghian S (2020) A Leech in the nasopharynx of an infant: A Case Report. Pediatr Dimensions (5). https://doi.org/10.15761/ PD.1000207

\section{Publisher's Note}

Springer Nature remains neutral with regard to jurisdictional claims in published maps and institutional affiliations.

\section{Submit your manuscript to a SpringerOpen ${ }^{\circ}$ journal and benefit from:}

- Convenient online submission

- Rigorous peer review

- Open access: articles freely available online

- High visibility within the field

- Retaining the copyright to your article

Submit your next manuscript at $\boldsymbol{\nabla}$ springeropen.com 